\title{
Pengaruh Pemberian Cookies Galohgor terhadap Kadar Vitamin A ASI Ibu Nifas
}

\author{
Effect of Galohgor Cookies on Vitamin A Content in Breast Milk of Postpartum Mothers \\ Ibnu Malkan Bakhrul IImi ${ }^{1,2}$, Rimbawan ${ }^{\star *}$, Katrin Roosita ${ }^{1}$, Zakiudin Munasir ${ }^{3}$ \\ 1Departemen Gizi Masyarakat, Fakultas Ekologi Manusia, IPB University, Bogor \\ 2Program Studi IImu Gizi, Fakultas IImu Kesehatan, Universitas Pembangunan Nasional "Veteran”, Jakarta \\ 3Departemen IImu Kesehatan Anak, Fakultas Kedokteran, Universitas Indonesia, Jakarta \\ *Korespondensi dengan penulis (rimbawan62@yahoo.com) \\ Artikel ini dikirim pada tanggal 26 Februari 2020 dan dinyatakan diterima tanggal 11 Mei 2020. Artikel ini juga dipublikasi secara online melalui \\ https://ejournal2.undip.ac.id/index.php/jatp. Hak cipta dilindungi undang-undang. Dilarang diperbanyak untuk tujuan komersial. \\ Diproduksi oleh Indonesian Food Technologists ${ }^{\circledR}$ (C2020
}

\begin{abstract}
Abstrak
Penelitian ini bertujuan untuk mengetahui pengaruh pemberian cookies galohgor terhadap kadar $\beta$-karoten dan retinol ASI ibu nifas. Penelitian ini menggunakan quasi-experimental design yang terdiri atas dua kelompok, yaitu kelompok kontrol $(n=9)$ dan kelompok intervensi $(n=9)$. Kelompok intervensi diberikan cookies galohgor 4 keping $\sim 40 \mathrm{~g} /$ hari, sedangkan kelompok kontrol diberikan cookies dengan jumlah yang sama namun cookies tersebut tanpa penambahan galohgor. Pemberian cookies dilakukan selama 40 hari pascamelahirkan. Sampel ASI diambil pada hari ke-14 dan hari ke-40 untuk dianalisis kadar $\beta$-karoten dan retinol ASI. Analisis konsumsi pangan juga dilakukan bersamaan dengan pengambilan sampel ASI. Hasil penelitian ini menunjukkan tidak terdapat perbedaan pada kadar $\beta$-karoten dan retinol ASI antara kelompok kontrol dan intervensi, baik pada hari ke-14 maupun hari ke-40 pascamelahirkan $(p>0,05)$, akan tetapi pemberian cookies galohgor relatif dapat mempertahankan kadar $\beta$-karoten ASI selama masa nifas. Oleh karena itu, penelitian ini menyimpulkan cookies galohgor dapat menjadi sumber $\beta$-karoten ASI.
\end{abstract}

Kata kunci: ASI, $\beta$-karoten, cookies galohgor, ibu nifas, retinol.

\section{Abstract}

This study was aimed to analyze the effect of galohgor cookies on $\beta$-carotene and retinol in breast milk of postpartum mothers. This study used quasi-experimental design consisting of two groups, the control group $(n=9)$ and the intervention group $(n=9)$. The intervention group was given galohgor cookies (4 pieces $\sim 40 \mathrm{~g} /$ day), while the control group was given cookies without galohgor as many as the intervention group. Cookies were given for 40 days after giving birth. Breast milk samples were taken on the $14^{\text {th }}$ day and $40^{\text {th }}$ day to analyze $\beta$-carotene and retinol content in breast milk along with the interview of food consumption. The results showed $\beta$-carotene and retinol content in breast milk did not differ significantly between the groups, both on the $14^{\text {th }}$ day and the $40^{\text {th }}$ day after giving birth ( $p>0.05)$. However, galohgor might maintain the $\beta$-carotene concentration in breast milk. Therefore, as conclusion, galohgor cookies may be provided as the source of $\beta$-carotene in breast milk.

Keywords: $\beta$-carotene, breast milk, galohgor cookies, postpartum mother, retinol.

\section{Pendahuluan}

Vitamin A merupakan salah satu zat gizi penting untuk mendukung pertumbuhan dan perkembangan (Gonçalves et al., 2016). Maden (2007) menyatakan bahwa vitamin A berperan dalam proliferasi dan diferensiasi sel-sel yang aktivitasnya sangat tinggi di periode awal kehidupan. Vitamin A juga merupakan sumber antioksidan yang penting bagi ibu nifas untuk menekan stres oksidatif pascamelahirkan (Bolisetty et al., 2002). Hingga di minggu ke-4 setelah melahirkan, tumor necrosis factor-a (TNF-a) yang merupakan salah satu penanda stres oksidatif meningkat sebesar 80 kali (Noor et al., 2008; Christian and Porter, 2014). Konsentrasi TNF-a ditemukan berhubungan negatif dengan produksi hormon insulin-like growth factor I (IGFI) yang merupakan hormon penting untuk pertumbuhan (Mao et al., 1999; Zhao et al. (2014). Stres oksidatif juga berhubungan dengan kualitas dan kuantitas air susu yang dihasilkan (Tanaka et al., 2008).

Kandungan vitamin A air susu ibu (ASI) ditemukan lebih rendah di negara-negara berkembang dan berhubungan erat dengan status vitamin $A$ ibu (Haskell and Brown 1999). Suplementasi vitamin A pada ibu hamil dan ibu nifas di Indonesia terbukti mampu meningkatkan kandungan vitamin A ASI (Muhilal et al., 1988; Stoltzfus et al., 1993; Muslimatun et al., 2001). Suplementasi ini juga berhasil menstimulasi pertumbuhan linear dan pertambahan berat badan lebih baik (Hadi et al., 2000). Keberhasilan ini diduga akibat masih rendahnya kecukupan vitamin A ibu di Indonesia (Haskell dan Brown 1999). Sebanyak 44,6\% ibu menyusui di Indonesia tidak mampu memenuhi estimated average requirement (EAR) vitamin A (Daniels et al., 2019).

Pemenuhan kebutuhan vitamin A ibu nifas hingga saat ini terus diupayakan oleh pemerintah. Pemberian kapsul merah dengan kandungan vitamin A $200.000 \mathrm{IU}$ masih menjadi program andalan. Upaya tersebut membantu penurunan jumlah balita dengan retinol $<20$ $\mu \mathrm{g} / \mathrm{dl}$ hingga kurang dari 5 persen (Sandjaja et al., 2013). Sebelumnya, Herman (2007) menemukan hampir separuh balita Indonesia memiliki kadar retinol $<20$ 
$\mu \mathrm{g} / \mathrm{dl}$. Akan tetapi, program ini membutuhkan biaya yang besar, tidak mengubah pola konsumsi dan defisiensi dapat kembali terjadi dengan munculnya penyakit (Herman, 2007). Oleh karena itu, peningkatan konsumsi pangan sumber vitamin A merupakan cara terbaik untuk memenuhi kebutuhan vitamin A ibu nifas secara berkelanjutan (Chakravarty, 2000).

Galohgor merupakan jamu tradisional yang berasal dari suku Sunda yang terbuat dari 56 jenis tanaman. Galohgor yang terbuat dari kacang-kacangan, batang-batangan, buah, rempah, dan temu-temuan biasa dikonsumsi oleh ibu nifas di suku tersebut (Roosita et al., 2003). Roosita et al. (2003) menemukan bahwa galohgor dapat meningkatkan produksi susu, mempercepat pencapaian waktu laktasi dan pemulihan uterus. Galohgor memiliki kandugan $\beta$-karoten yang cukup tinggi $(21,37 \mathrm{mg} / 100 \mathrm{~g}$ ekstrak) sehingga mampu meningkatkan kapasitas antioksidan dan menurunkan stres oksidatif penderita diabetes tipe 2 (Roosita 2014; Setyaningsih et al., 2017). Pemberian $\beta$-karoten dan zink selama kehamilan terbukti mampu meningkatkan kadar vitamin A ASI sebesar 80\% (Dijkhuizen et al., (2004). Hasil tersebut didukung oleh Rice et al., (1999) yang menemukan adanya efek menguntungkan pada status vitamin A ibu dan bayi setelah suplementasi $\beta$-karoten.

Galohgor yang terbuat dari berbagai jenis tanaman memiliki aroma dan cita rasa yang khas (Damayanti et al., 2018). Akan tetapi, tidak semua orang terbiasa dengan aroma dan cita rasa herbal sehingga secara umum sulit dikonsumsi (Jokar et al., 2017). Damayanti et al. (2018) dan Ma'rifah et al. (2019) telah meneliti cookies galohgor yang telah terbukti menurunkan lemak viseral pasien penderita diabetes tipe 2 dan menurunkan stress oksidatif pada ibu nifas. Dengan memanfaatkan cookies galohgor yang telah diteliti tersebut, penelitian ini bertujuan untuk menganalisis kadar $\beta$-karoten dan retinol ASI ibu nifas setelah diberikan cookies galohgor.

\section{Materi dan Metode}

Materi

Bahan yang digunakan dalam penelitian ini yaitu cookies galohgor yang mengandung $1 \mathrm{~g}$ galohgor. Cookies galohgor diproduksi oleh CV. Nutrasetikal Galohgor, Bogor (P-IRT No: 2063201010485-22). Serbuk galohgor yang digunakan terdaftar pada paten dengan Nomor IDP000058958. Cookies tanpa penambahan galohgor digunakan sebagai kontrol juga diproduksi oleh CV. Nutrasetikal Galohgor, Bogor. Bahan utama pembuatan cookies yaitu tepung terigu, kuning telur, susu bubuk, gula, margarin, garam dan santan. Pengambilan ASI dilakukan untuk menganalisis kandungan kandungan retinol dan $\beta$-karoten. Alat-alat yang dibutuhkan untuk pengambilan ASI seperti, breastpump electric spectra S1 plus, botol ASI kaca merk BKA. Pelarut yang digunakan untuk ekstraksi $\beta$ karoten yaitu etanol:butanol (50:50:5 BHT/ml), sedangkan untuk ekstraksi retinol yaitu asetonitril:metanol (20:50:5 mg BHT/ ml). Instrumen yang digunakan untuk kedua analisis tersebut yaitu HPLC Prominance-I LC-2030C (Shimadzu, Jepang) yang dilengkapi dengan detektor PDA dan pompa nomor 515 dengan laju alir $1,5 \mathrm{ml} / \mathrm{menit}$ dan suhu kolom ambient. Kolom yang digunakan untuk analisis retinol yaitu jenis Lichrosper RP18 (Sigma, USA), sedangkan untuk analisis $\beta$-karoten yaitu Luna C18 (Phenomenex, USA). Fase bergerak yang digunakan untuk analisis retinol yaitu akuabides dan metanol, sedangkan campuran asetonitril dan isopropanol (65:35) untuk analisis $\beta$ - karoten.

\section{Metode}

Penelitian ini menggunakan quasi-experimental design yang dilaksanakan pada bulan Juli 2018 - Mei 2019. Penelitian dilaksanakan di beberapa Puskesmas di Kota Bogor yaitu, Puskesmas Pancasan, Puskesmas Cipaku, Puskesmas Kayumanis, Puskesmas Sempur, Puskesmas Warung Jambu. Kadar retinol dan $\beta$-karoten diukur menggunakan high liquid performance chromatography (HPLC). Selain itu, analisis konsumsi pangan subjek dianalisis dengan menggunakan recall 2 x 24 jam. Penelitian ini telah disetujui oleh Komisi Etik yang melibatkan subjek manusia, Institut Pertanian Bogor dengan No. 081/IT3.KEPMSM-IPB/SK/2018.

\section{Subjek Penelitian}

Subjek penelitian ini merupakan ibu nifas berusia 20-35 tahun dengan kehamilan ke-2 hingga ke-5. Ibu tidak memiliki penyakit kronis dan bukan perokok serta dapat berkomunikasi dengan baik. Ibu terlebih dahulu menandatangani informed consent sebelum mengikuti penelitian. Ibu nifas dengan bayi lahir prematur dan atau persalinan dilakukan secara operasi sesar dieksklusi dari penelitian. Sebanyak 18 ibu nifas dibutuhkan dalam penelitian ini yang dibagi menjadi dua kelompok, yaitu kelompok kontrol dan kelompok intervensi. Jumlah sampel ditentukan dengan menggunakan rumus Lemeshow et al. (1990) dengan tingkat kepercayaan (1a) sebesar $90 \%$ dan kekuatan uji (1- $\beta$ ) sebesar $80 \%$.

\section{Prosedur Intervensi}

Penentuan kandidat subjek dilakukan pada saat ibu dengan usia kehamilan 30-33. Subjek yang memenuhi kriteria dibagi menjadi dua kelompok, yaitu kelompok intervensi dan kelompok kontrol. Cookies diberikan dari hari ke-1 hingga hari ke-40 pascamelahirkan. Kelompok intervensi diberikan cookies galohgor sebanyak 4 keping $\sim 40 \mathrm{~g} /$ hari, sedangkan kelompok kontrol diberikan cookies kontrol dengan jumlah yang sama. Dengan menggunakan dosis tersebut, Ma'rifah et al. (2019) melaporkan bahwa konsumsi cookies galohgor dapat menurunkan stres oksidatif pada ibu nifas. Sampel ASI diambil sebanyak $50 \mathrm{ml}$ kemudian disimpan di dalam freezer pada suhu $80{ }^{\circ} \mathrm{C}$ untuk kemudian dianalisis. Pengambilan sampel ASI dilakukan pada hari ke-14 dan hari ke-40. Pada hari ke-14, ASI sudah tergolong matang dan kandungan gizinya, termasuk $\beta$-karoten, relatif tidak berubah dalam beberapa bulan ke depan (Macy, 1949; Ballard and Morrow, 2013). Kandungan $\beta$-karoten ASI terlihat sangat tinggi pada awal laktasi kemudian menurun dan stabil pada ASI transisi. Kandungan tersebut relatif konstan 
pada ASI matang (Gossage et al., 2002; Zarban et al., 2009). Hari ke-40 pascamelahirkan ditentukan sebagai titik kedua pengambilan sampel ASI karena merupakan akhir dari periode nifas (Schauberger et al.,1992; Ros et al., 2001). Pengambilan data konsumsi pangan subjek dilakukan pada hari yang sama dengan pengambilan sampel ASI subjek. Kepatuhan subjek dikontrol dengan cara cookies diberikan 5 hari sekali dan dimonitor dengan pesan singkat menggunakan telepon genggam setiap hari.

\section{Prosedur Analisis $\beta$-karoten dan Retinol dengan HPLC} Jumlah sampel ASI yang digunakan untuk analisis yaitu $40 \mathrm{ml}$. Sebanyak $100 \mu \mathrm{l}$ pelarut ekstraksi dicampurkan dengan sampel. Campuran dikocok hingga merata dan dilanjutkan dengan sentrifugasi pada kecepatan 12.000 rpm selama 3 detik dan pada suhu 8 oC. Supernatan yang dihasilkan diambil sebanyak $20 \mu \mathrm{l}$ untuk diinjeksikan ke HPLC. Analisis $\beta$-karoten dilakukan pada panjang gelombang $450 \mathrm{~nm}$ di menit ke $7-10$, sedangkan retinol pada panjang gelombang 325 $\mathrm{nm}$ di menit ke 4-6. Standar $\beta$-karoten dan retinol yang digunakan adalah certified reference material (CRM), 986e Fat Soluble Vitamins, Carotenoids and Cholesterol in Human Serum dari National Institute of Standards and Technology (Aaran and Nakari, 1988).

\section{Analisis Statistik}

Data dilaporkan dalam rata-rata dan standar deviasi. Perbedaan antar kelompok dianalisis dengan independent $t$-test, sedangkan perbedaan dalam satu kelompok dianalisis dengan paired-dependent t-test. Perbedaan yang signifikan ditetapkan pada $a=0,05$.

\section{Hasil dan Pembahasan}

\section{Asupan Vitamin A Subjek}

Asupan vitamin $A$ dan $\beta$-karoten subjek secara statistik tidak berbeda signifikan (Tabel 1). Meskipun demikian, asupan vitamin A dan $\beta$-karoten pada kelompok intervensi relatif lebih tinggi dibandingkan dengan kelompok kontrol. Kondisi ini dapat disebabkan oleh perbedaan kandungan kedua zat gizi tersebut yang tidak terlalu besar antara cookies kontrol dan intervensi. Kandungan gizi cookies yang digunakan dalam penelitian ini serta data asupan yang lebih lengkap telah dipublikasikan oleh Ma'rifah et al. (2019).

\section{Kadar $\beta$-karoten dan Retinol ASI}

Hasil penelitian ini menunjukkan pemberian cookies galohgor tidak menyebabkan adanya perubahan pada kadar $\beta$-karoten ASI. Kadar $\beta$-karoten ASI pada hari ke-14 dan hari ke-40 pada kelompok kontrol tidak berbeda signifikan dengan kelompok intervensi $(p>0,05)$. Akan tetapi, kadar $\beta$-karoten ASI pada kelompok intervensi relatif mengalami peningkatan dari hari ke-14 hingga hari ke-40, sedangkan pada kelompok kontrol terlihat mengalami penurunan. Meskipun demikian, perubahan pada kedua kelompok tidak berbeda signifikan (Tabel 2). Sama halnya dengan kadar retinol ASI, penelitian ini menemukan tidak adanya perbedaan antar kelompok, baik di hari ke-14 maupun di hari ke-40. Selain itu, dalam satu kelompok, perubahan retinol di hari ke-14 dan hari ke-40 tidak berbeda signifikan di kedua kelompok $(p>0,05)$ (Tabel 3$)$.

Galohgor telah lama digunakan oleh ibu nifas suku Sunda karena dipercaya mampu mempercepat pemulihan pascamelahirkan dan meningkatkan produksi ASI (Roosita et al., 2003). Roosita et al. (2014) melaporkan bahwa $\beta$-karoten yang merupakan karotenoid utama yang terkandung dalam galohgor berperan dalam memicu diferensiasi sel kelenjar mamae ( $\mathrm{HC11}$ ) yang ditandai dengan perkembangan mamosfer, ekspresi gen koneksin (Cx-43) dan $\beta$-kasein (Csn2). Meningkatnya kebutuhan vitamin $A$ saat menyusui hingga $90 \%$ membuat $\beta$-karoten menjadi sumber vitamin A utama karena pemberian vitamin A dosis tinggi pada ibu menyusui tidak direkomendasikan akibat efek toksik yang mungkin dapat ditimbulkan (Strobel et al., 2007). Pemenuhan kebutuhan vitamin $A$ pada ibu pascamelahirkan dapat memberikan efek yang menguntungkan karena dapat membantu untuk menstabilkan stres oksidatif yang terjadi selama kehamilan. Stres oksidatif berhubungan dengan rendahnya kuantitas, kandungan protein, asam askorbat, dan asam amino sulfur dari air susu yang dihasilkan (Tanaka et al., 2008). Akan tetapi, hasil penelitian ini menunjukkan tidak adanya perbedaan pada kadar $\beta$-karoten dan vitamin A antara kelompok intervensi dan kelompok kontrol. Hasil ini tidak sejalan dengan hasil penelitian sebelumnya yang menunjukkan zat-zat gizi tertentu, seperti asam lemak, vitamin A, D, E, $\mathrm{K}, \mathrm{B} 6, \mathrm{~B} 12$, folat, yodium dan selenium serta karotenoid yang terkandung dalam ASI bergantung pada diet ibu (Lönnerdal, 1986; Canfield et al., 2003; Keikha et al., 2017).

Tabel 1. Asupan vitamin A dan $\beta$-karoten

\begin{tabular}{lcc}
\hline Asupan Gizi & Kelompok kontrol & Kelompok Intervensi \\
\hline Vitamin A $(\mu \mathrm{g})$ & $1022,00 \pm 405,4$ & $1172,20 \pm 376,8$ \\
$\beta$-karoten $(\mathrm{mg})$ & $10,75 \pm 3,79$ & $11,59 \pm 4,2$ \\
\hline
\end{tabular}

Keterangan: data ditampilkan dalam bentuk rata-rata \pm standar deviasi

Tabel 2. Kandungan $\beta$-karoten ASI pada hari ke-14 dan hari ke-40 pascamelahirkan

Titik pengukuran Kelompok kontrol Kelompok intervensi

\begin{tabular}{lcc} 
& $(\mathrm{mg} / \mathrm{kg})$ & $(\mathrm{mg} / \mathrm{kg})$ \\
\hline Hari ke-14 & $0,953 \pm 0,769$ & $0,455 \pm 0,527$ \\
Hari ke-40 & $0,472 \pm 0,369$ & $0,691 \pm 0,462$ \\
Perubahan & $-0,481 \pm 0,989$ & $+0,235 \pm 0,898$ \\
\hline
\end{tabular}

Keterangan: data ditampilkan dalam bentuk rata-rata \pm standar deviasi

Tabel 3. Kandungan retinol ASI pada hari ke-14 dan hari ke40 pascamelahirkan

\begin{tabular}{lcc}
$\begin{array}{l}\text { Titik } \\
\text { Pengukuran }\end{array}$ & $\begin{array}{c}\text { Kelompok kontrol } \\
(\mu \mathrm{g} / 100 \mathrm{ml})\end{array}$ & $\begin{array}{c}\text { Kelompok intervensi } \\
(\mu \mathrm{g} / 100 \mathrm{ml})\end{array}$ \\
\hline Hari ke 14 & $38,284 \pm 6,451$ & $41,405 \pm 15,438$ \\
Hari ke 40 & $67,312 \pm 43,291$ & $55,651 \pm 33,659$ \\
Perubahan & $+29,027 \pm 42,648$ & $+14,245 \pm 42,359$ \\
\hline
\end{tabular}

Keterangan: data ditampilkan dalam bentuk rata-rata \pm standar deviasi

Disisi lain, adapula penelitian yang melaporkan bahwa bahwa keadaan gizi ibu relatif tidak mempengaruhi komposisi ASI (Gossage et al., 2002; Innis, 2014). Meskipun demikian, pemberian cookies 
galohgor mampu mempertahankan kadar $\beta$-karoten ASI yang biasanya mengalami penurunan setelah beberapa minggu pascamelahirkan (Schweigert et al., 2004).

Kadar $\beta$-karoten dan vitamin A di periode awal menyusui yang sangat tinggi dan sudah mencapai titik jenuh diduga menjadi alasan tidak adanya perubahan yang signifikan dari kedua zat gizi tersebut setelah diberikan intervens (Schweigert et al., 2004). Hal ini didukung oleh Gossage et al., (2002) yang memberikan suplementasi $\beta$-karoten kepada ibu nifas dan menemukan tidak adanya perubahan pada $\beta$-karoten, retinol, karotenoid lain dan a-tokoferol. Adanya mekanisme kompensasi merupakan teori yang juga dapat dijadikan penjelasan mengenai hasil penelitian ini. Mitoulas et al., (2002) menemukan lemahnya hubungan antara komposisi ASI dengan diet ibu diduga disebabkan oleh adanya mekanisme kompensasi untuk menjaga kandungan gizi ASI relatif konstan. Mekanisme ini bertujuan untuk menjamin terpenuhinya kebutuhan bayi dengan cara memobilisasi cadangan-cadangan di hati ketika asupan gizi tidak mencukupi untuk memproduksi ASI dengan jumlah yang cukup (Dror and Allen, 2018). Namun, teori ini utamanya berlaku untuk zat gizi makro dan ketika ibu tidak mengalami defisiensi (Mitoulas et al., 2002; Dron and Allen, 2018). Selain itu, tubuh diduga lebih memanfaatkan $\beta$-karoten sebagai antioksidan untuk membantu mempercepat proses penurunan stres oksidatif yang terjadi pada ibu nifas (Holt et al., 2009). Ma'rifah et al. (2019) juga menemukan bahwa cookies galohgor mampu meningkatkan serum $\beta$-karoten darah dan menurunkan kadar malondialdehid (MDA) ibu nifas.

\section{Kesimpulan}

Pemberian cookies galohgor tidak signifikan meningkatkan asupan $\beta$-karoten dan vitamin $A$ ibu nifas. Hasil penelitian ini juga menunjukkan bahwa pemberian cookies galohgor kepada ibu nifas tidak berdampak signifikan pada kadar $\beta$-karoten dan retinol ASI. Meskipun tidak signifikan, pemberian cookies galohgor relatif dapat mempertahankan kadar $\beta$-karoten ASI selama masa nifas.

\section{Ucapan Terima Kasih}

Penelitian ini disponsori oleh Lembaga Pengelola Dana Pendidikan (LPDP) Kementerian Keuangan Republik Indonesia dan CV Nutrasetikal Galohgor.

\section{Daftar Pustaka}

Aaran, R. K., Nikkari, T. 1988. HPLC method for the simultaneous determination of beta-carotene, retinol and alpha-tocopherol in serum. Journal of Pharmaceutical and Biomedical Analysis 6(68):853-857. DOI: 10.1016/0731-7085(88)801018.

Ballard, O., Morrow, A.L. 2013. Human milk composition: nutrients and bioactive factors. Pediatric Clinics 60(1):49-74. DOI: 10.1016/j.pcl.2012.10.002.

Bolisetty, S., Naidoo, D., Lui, K., Koh, T.H.H.G., Watson, D., Montgomery, R., Whitehall, J. 2002. Postnatal changes in maternal and neonatal plasma antioxidant vitamins and the influence of smoking.
Archives of Disease in Childhood-Fetal and Neonatal Edition 86(1):F36-F40. DOI:10.1136/fn.86.1.f36.

Canfield, L.M., Clandinin, M.T., Davies, D.P., Fernandez, M.C., Jackson, J., Hawkes, Goldman, W.J., Pramuk, K., Reyes, H., Sablan, B., Sonobe, T., Bo, X. 2003. Multinational study of major breast milk carotenoids of healthy mothers. European Journal of Nutrition 42(3):133-141. DOI:10.1007/s00394-003-0403-9.

Chakravarty, I. 2000. Food-based strategies to control vitamin A deficiency. Food and Nutrition Bulletin 21(2):135-143.

DOI:10.1177\%2F156482650002100205.

Christian, L.M., Porter, K. 2014. Longitudinal changes in serum proinflammatory markers across pregnancy and postpartum: effects of maternal body mass index. Cytokine 70(2):134-140. DOI:10.1016/j.cyto.2014.06.018.

Damayati, R.P., Roosita, K., Sulaeman, A. 2018. Effect of galohgor cookies and powder drinks on visceral adipose tissue and lipid profile in patients with type 2 diabetes mellitus. Jurnal Gizi dan Pangan 13(3):137-144. DOI:10.25182/jgp.2018.13.3.137144.

Daniels, L., Gibson, R.S., Diana, A., Haszard, J.J., Rahmannia, S., Luftimas, D.E., Hampel, D., Shahab-Ferdows, S., Reid, M., Lammers, Y., Allen, L.H., Houghton, L.A. 2019. Micronutrient intakes of lactating mothers and their association with breast milk concentrations and micronutrient adequacy of exclusively breastfed Indonesian infants. American Journal of Clinical Nutrition 110(2):391-400. DOI:10.1093/ajcn/nqz047.

Dijkhuizen, M.A., Wieringa, F.T., West, C.E. 2004. Zinc plus $\beta$-carotene supplementation of pregnant women is superior to $\beta$-carotene supplementation alone in improving vitamin $A$ status in both mothers and infants. The American Journal of Clinical Nutrition 80(5):1299-1307. DOI:10.1093/ajcn/80.5.1299.

Dror, D.K., Allen, L.H. 2018. Overview of nutrients in human milk. Advances in Nutrition 9(suppl_1):278S-294S. DOI:10.1093/advances/nmy022.

Gonçalves, A., Estevinho, B. N., Rocha, F. 2016. Microencapsulation of vitamin A: A review. Trends in Food Science \& Technology 51:76-87. DOI:10.1016/j.tifs.2016.03.001.

Gossage, C.P., Deyhim, M., Yamini, S., Douglass, L.W., Moser-Veillon, P.B. 2002. Carotenoid composition of human milk during the first month postpartum and the responses to $\beta$-carotene supplementation. The American Journal of Clinical Nutrition 76(1):193-197. DOI:10.1093/ajcn/76.1.193.

Hadi, H., Stoltzfus, R.J., Dibley, M. J., Moulton, L.H., West Jr, K.P., Kjolhede, C.L., Sadjimin, T. 2000. Vitamin A supplementation selectively improves the linear growth of Indonesian preschool children: results from a randomized controlled trial. The 
American Journal of Clinical Nutrition 71(2):507513. DOI:10.1093/ajcn/71.2.507.

Haskell, M.J., Brown, K.H. 1999. Maternal vitamin A nutriture and the vitamin A content of human milk. Journal of Mammary Gland Biology and Neoplasia. 4(3):243-257. DOI:10.1023/A:1018745812512.

Herman, S. 2007. Masalah kurang vitamin A (KVA) dan prospek penanggulangannya. Media Litbang Kesehatan 4:40-44. DOI:10.22435/mpk.v17i4 Des.824.

Holt, E.M., Steffen, L.M., Moran, A., Basu, S., Steinberger, J., Ross, J.A., Hong, C., Sinaiko, A.R. 2009. Fruit and vegetable consumption and its relation to markers of inflammation and oxidative stress in adolescents. Journal of the American Dietetic Association 109(3):414-421. DOI: 10.1016/j.jada.2008.11.036.

Innis, S. M. 2014. Impact of maternal diet on human milk composition and neurological development of infants. The American Journal of Clinical Nutrition 99(3):734S-741S. DOI:10.3945/ajcn.113.072595.

Jokar, N.K., Noorhosseini, S.A., Allahyari, M.S., Damalas, C.A. 2017. Consumers' acceptance of medicinal herbs: an application of the technology acceptance model (TAM). Journal of Ethnopharmacology 207:203-210. DOI:10.1016/j.jep.2017.06.017.

Keikha, M., Bahreynian, M., Saleki, M., Kelishadi, R. 2017. Macro-and micronutrients of human milk composition: Are they related to maternal diet? A comprehensive systematic review. Breastfeeding Medicine

12(9):517-527. DOI:10.1089/bfm.2017.0048.

Lemeshow, S., Hosmer, D. W., Klar, J., Lwanga, S.K., World Health Organization. 1990. Adequacy of Sample Size in Health Studies. Wiley, Chichester.

Lönnerdal, B.O. 1986. Effects of maternal dietary intake on human milk composition. The Journal of Nutrition 116(4):499-513.

DOI: 10.1093/jn/116.4.499.

Ma'rifah, B., Roosita, K., Sinaga, T. 2019. The galohgor nutraceutical cookies effects on $\beta$-carotene serum and oxidative stress of postpartum mothers. Preventive Nutrition and Food Science 24(4):381386. DOI: 10.3746/pnf.2019.24.4.381.

Macy, I.G. 1949. Composition of human colostrum and milk. American Journal of Diseases of Children 78(4):589-603.

DOI:10.1001/archpedi.1949.02030050604009.

Maden, M. 2007. Retinoic acid in the development, regeneration and maintenance of the nervous system. Nature Reviews Neuroscience 8(10):755765. DOI:10.1038/nrn2212.

Mao, Y., Ling, P.R., Fitzgibbons, T.P., McCowen, K.C., Frick, G.P., Bistrian, B.R., Smith, R.J. 1999. Endotoxin-induced inhibition of growth hormone receptor signaling in rat liver in vivo. Endocrinology 140(12):5505-5515. DOI:10.1179/2046905514Y.0000000134.
Mitoulas, L.R., Kent, J.C., Cox, D.B., Owens, R.A., Sherriff, J.L., Hartmann, P.E. 2002. Variation in fat, lactose and protein in human milk over $24 \mathrm{~h}$ and throughout the first year of lactation. British Journal of Nutrition 88(1):29-37. DOI:10.1079/BJN2002579.

Muhilal, P.D., Idjradinata, Y.R., Muherdiyantiningsih, K.D. 1988. Vitamin A-fortified monosodium glutamate and health, growth, and survival of children: a controlled field trial. American Journal of Clinical Nutrition 48(5):1271-1276. DOI:10.1093/ajcn/48.5.1271.

Muslimatun, S., Schmidt, M. K., West, C. E., Schultink, W., Hautvast, J. G., Karyadi, D. 2001. Weekly vitamin $A$ and iron supplementation during pregnancy increases vitamin A concentration of breast milk but not iron status in Indonesian lactating women. Journal of Nutrition 131(10):2664-2669. DOI:10.1093/jn/131.10.2664.

Noor, N., Islam, N., Moin, S., Mahdi, A.A., Jaiswal, S., Bano, F. 2008. Normal delivery induced stress alters glutathione peroxidase and TNF-a in elderly primigravidas mononuclear cells. Indian Journal of Clinical Biochemistry 23(3):227-232. DOI:10.1007/s12291-008-0051-1.

Rice, A.L., Stoltzfus, R.J., de Francisco, A., Chakraborty, J., Kjolhede, C.L., Wahed, M.A. 1999. Maternal vitamin $A$ or $\beta$-carotene supplementation in lactating Bangladeshi women benefits mothers and infants but does not prevent subclinical deficiency. The Journal of Nutrition 129(2):356365. DOI: 10.1093/jn/129.2.356.

Roosita, K. 2014. Peranan $\beta$-karoten dan nutraseutikal galohgor dalam proliferasi, diferensiasi, dan ekspresi gen sel epitel usus (CMT-93) dan sel kelenjar mammae (HC11). Disertasi, Institut Pertanian Bogor, Bogor.

Roosita, K., Kusharto, C.M., Kusumorini, N., Manalu, W. 2003. The effect of traditional herbs medicine "Galohgor" on uterus involution and milk production of rats (Rattus sp.) made in Sukajadi Village, Tamansari Subdistrict, Bogor, Indonesia. Proceedings, Symposium Series 1. International Symposium on Biomedicines: Biodiversity on Traditional Biomedicines for Human Health and Welfare. Biopharmaca Research Center, Bogor Agricultural University, Bogor, Indonesia, September 18-19. Page 18-19.

Roosita, K., Rimbawan, S.M., Djuwita, I., Damanik, M.R., Kusharto, C.M., Damayanthi, E., Nomura, N. 2014. $\beta$-carotene roles in proliferation and differentiation, connexin and $\beta$-casein gene expression of mammary gland cells line. Malaysian Journal of Nutrition 20(1):113-119. DOI:10.5935/abc.20130160.

Ros, H.S., Lichtenstein, P., Bellocco, R., Petersson, G., Cnattingius, S. 2001. Increased risks of circulatory diseases in late pregnancy and puerperium. Epidemiology 12(4):456-460. DOI:10.1097/00001648-200107000-00016. 
Sandjaja, S., Budiman, B., Harahap, H., Ernawati, F., Soekatri, M., Widodo, Y., Sumedi, E., Rustan, E., Sofia, G., Syaried, S.N., Khouw, I. 2013. Food consumption and nutritional and biochemical status of 0 5-12-year-old Indonesian children: the SEANUTS study. British Journal of Nutrition 110(S3):S11-S20.

DOI:10.1017/S0007114513002109.

Schauberger, C,W., Rooney, B.L., Brimer, L.M. 1992. Factors that influence weight loss in the puerperium. Obstetrics and Gynecology 79(3):424-429. DOI:10.1097/00006250199203000-00020.

Schweigert, F.J., Bathe, K., Chen, F., Büscher, U., Dudenhausen, J.W. 2004. Effect of the stage of lactation in humans on carotenoid levels in milk, blood plasma and plasma lipoprotein fractions. European Journal of Nutrition 43(1):39-44. DOI:10.1007/s00394-004-0439-5.

Setyaningsih, S., Katrin, R., Damayanthi, E. 2017. Efek produk galohgor terhadap aktivitas antioksidan dan penurunan stres oksidatif Diabetes Melitus tipe 2. Media Kesehatan Masyarakat Indonesia Universitas Hasanuddin 13(4):310-318. DOI:10.30597/mkmi.v13i4.1930.

Stoltzfus, R. J., Hakimi, M., Miller, K. W., Rasmussen, K. M., Dawiesah, S., Habicht, J. P., Dibley, M. J. 1993. High dose vitamin A supplementation of breast-feeding Indonesian mothers: effects on the vitamin A status of mother and infant. Journal of Nutrition 123(4):666-675.
Strobel, M., Tinz, J., Biesalski, H. K. 2007. The importance of $\beta$-carotene as a source of vitamin $A$ with special regard to pregnant and breastfeeding women. European Journal of Nutrition 46(9):1-20. DOI:10.1007/s00394-007-1001-z.

Tanaka, M., Kamiya, Y., Suzuki, T., Kamiya, M., Nakai, Y. 2008. Relationship between milk production and plasma concentrations of oxidative stress markers during hot season in primiparous cows. Animal Science Journal 79(4):481-486. DOI:10.1111/j.1740-0929.2008.00553.x

Zarban, A., Taheri, F., Chahkandi, T., Sharifzadeh, G., Khorashadizadeh, M. 2009. Antioxidant and radical scavenging activity of human colostrum, transitional and mature milk. Journal of Clinical Biochemistry and Nutrition 45(2):150-154. DOI: 10.3164/jcbn.08-233

Zhao, Y., Xiao, X., Frank, S.J., Lin, H.Y., Xia, Y. 2014. Distinct mechanisms of induction of hepatic growth hormone resistance by endogenous IL-6, TNF-a, and IL-1 $\beta$. American Journal of Physiology-Endocrinology and Metabolism 307(2):E186-E198. DOI: 10.1152/ajpendo.00652.2013. 